\title{
HUBUNGAN PEMBERIAN ASI EKSKLUSIF DENGAN STATUS GIZI BALITA USIA 6-24 BULAN DI KAMPUNG KAJANAN, BULELENG
}

\author{
M Kurnia Widiastuti Giri ${ }^{1}$, I W Muliarta ${ }^{2}$, N.P Dewi Sri Wahyuni ${ }^{3}$. \\ 1,3 Jurusan Pendidikan Jasmani Kesehatan dan Rekreasi, ${ }^{2} J u r u s a n$ Pendidikan Kepelatihan \\ Olahraga \\ Fakultas Olahraga dan Kesehatan Úniversitas Pendidikan Ganesha Bali \\ e-mail:muliarta_iwayan@yahoo.com,kurniawidiastutimade@yahoo.com
}

\begin{abstract}
Abstrak
Penelitian ini bertujuan untuk mengetahui hubungan antara pemberian ASI Eksklusif dengan status gizi balita usia 6-24 bulan di Kelurahan Kampung Kajanan, Kecamatan Buleleng, dengan metode observasional menggunakan pendekatan cross sectional dengan tehnik analisis data korelasional.

Diperoleh data penelitian bahwa $9 \%$ ibu yang tidak memberikan ASI Eksklusif memiliki balita dengan status gizi diatas garis merah dan 1,3\% memiliki status gizi bawah garis merah, sedangkan $74,4 \%$ ibu yang memberikan ASI Eksklusif memiliki balita dengan status gizi diatas garis merah dan $15,4 \%$ memiliki status gizi di bawah garis merah. Hasil uji korelasi nilai signifikansi $p=0,000(p<0,05)$, sehingga disimpulkan ada hubungan antara pemberian ASI Eksklusif dengan status gizi balita usia 6-24 bulan.
\end{abstract}

Kata kunci : ASI Eksklusif, status gizi balita

\begin{abstract}
The objective of this research is to determine the relationship of Exclusive breast feeding history and nutritional status on 6 to 24 month old children in Kampung Kajanan village. This study was an observational analytic types of quantitative research with cross sectional approach. Analize technique of the correlation of variables was used correlationalanalysis.

Babies whom had given exclusive breast feed by their mother have $74,4 \%$ under red line nutritional status and 15,4 above that line on Kartu Menuju Sehat (KMS). While babies without that history have $1,3 \%$ under red line nutritional status and $9 \%$ above that line on KMS. That research data analysis showed that statistically significant ( $p$ value on 0,000 is lower than 0,005)

There is a significant correlation between Exclusive breast feeding history to nutritional status on 6 to 24 month old children in Kampung Kajanan village at Buleleng District.
\end{abstract}

Keywords: exclusive breast feeding, nutritional status

PENDAHULUAN

Masalah gizi pada hakikatnya adalah masalah kesehatan masyarakat, namun penanganannya tidak hanya dapat dilakukan dengan pendekatan medis dan pelayanan kesehatan saja. Penyebab timbulnya masalah gizi adalah multifaktorial,

$$
\begin{aligned}
& \text { oleh karena itu pendekatan } \\
& \text { penanggulangannya harus melibatkan } \\
& \text { berbagai sektor terkait terutama ibu balita itu } \\
& \text { sendiri. }
\end{aligned}
$$

Saat ini Negara Indonesia sedang mengalami krisis, baik dalam bidang energi, pangan, kesehatan maupun sumber daya 
alam yang disebabkan beberapa faktor salah satunya adalah kebijakan pemerintah dan tindakan masyarakat yang mengeksploitasi dan memanfaatkan alam secara berlebihan, sehingga semakin banyak masalah bermunculan diantaranya adalah kemiskinan, krisis pangan dan gizi buruk. Menjadi tugas penting bagi pemerintah serta masyarakat untuk menyelesaikan masalah tersebut. Secara umum masalah gizi di Indonesia terutama KEP (Kurang Energi Protein) masih lebih tinggi daripada Negara ASEAN lainnya. Di tingkat dunia dikatakan ada sedikitnya 17.289 balita meninggal setiap hari karena kelaparan dan kurang gizi dengan segala akibat yang ditimbulkannya (Supariasa, 2001).

Pemberian ASI, khususnya ASI eksklusif, prevalensinya masih terbilang rendah di Indonesia. SDKI tahun 2007 menyebutkan hanya $32,3 \%$ ibu yang memberikan ASI eksklusif selama 6 bulan kapada bayinya.

Hasil survei sensus nasional diketahui bahwa persentase balita yang bergizi baik sebesar $71,88 \%$ pada tahun 2002 dan pada tahun 2003 turun menjadi $69,59 \%$. Balita dengan gizi kurang/buruk sebesar 25,82\% pada tahun 2002 dan meningkat menjadi $28,17 \%$ pada tahun 2003 (BPS, 2003).

Prevalensi balita sangat kurus secara nasional masih cukup tinggi yaitu $6,2 \%$. Besarnya masalah kurus pada balita yang masih merupakan masalah kesehatan masyarakat (public health problem) adalah jika prevalensi kurus > $>5 \%$. Masalah kesehatan masyarakat sudah dianggap serius bila prevalensi kurus antara 10,1\% $15,0 \%$, dan dianggap kritis bila prevalensi kurus sudah di atas 15,0\% (UNHCR). Secara nasional prevalensi kurus pada balita adalah 13,6\%. Hal ini berarti bahwa masalah kurus di Indonesia masih merupakan masalah kesehatan masyarakat yang serius. Bahkan, dari 33 provinsi, 18 provinsi di antaranya masuk dalam kategori kategori kritis (prevalensi kurus >15\%), 12 provinsi pada kategori serius (prevalensi kurus antara 10-15\%) (Riskesdas, 2007).

Bila jumlah balita di Bali tercatat $12 \%$ dari sekitar 3,5 juta penduduk Bali, maka 0,46\%-nya berstatus gizi buruk. Artinya dapat diperkirakan prevalensi balita berstatus gizi buruk berjumlah 1.932 bocah. Dan apabila dilihat dari kabupaten/kota di Bali tampak persentase tertinggi berada di wilayah Buleleng dan Karangasem yang terdata $0,75 \%$. Di wilayah Buleleng pada tahun 2006 tercatat sebanyak tujuh orang balita dengan status gizi buruk dan pada tahun 2007 jumlah gizi buruk yaitu sebanyak 4 orang yang tersebar di wilayah Desa Anturan, Tukad Sumaga dan Musi, serta Desa Sidatapa.

Daerah perkotaan diwakili oleh wilayah kerja Puskesmas Buleleng I dimana Kelurahan Kampung Kajanan terdapat di dalamnya sehingga kelurahan Kampung Kajanan tentunya merupakan kelurahan di wilayah perkotaan. Hal ini berdasarkan pertimbangan lokasi kelurahan yang dekat dengan pusat pemerintahan Kecamatan, yaitu $3.5 \mathrm{~km}$. Di wilayah kerja Puskesmas Buleleng I, data yang diperoleh berdasarkan pencatatan BB (Berat Badan) /Umur balita usia 1-3 tahun pada bulan Juni 2011 tercatat balita dengan status gizi kurang sebanyak 32 anak sementara 20 anak dalam status gizi buruk.

Berdasarkan studi pendahuluan yang telah penulis lakukan, Kelurahan Kampung Kajanan merupakan suatu kelurahan yang terletak diwilayah kota Singaraja adalah pemukiman yang padat penduduk dengan luas wilayah $39,6 \mathrm{ha} / \mathrm{m} 2$ terbagi dalam 12 Rukun Warga (RW). Kelurahan Kampung Kajanan dihuni oleh 1361 kepala keluarga dengan jumlah penduduk seluruhnya yakni sejumlah 4681 penduduk. Jumlah balita di kelurahan ini seluruhnya 366 anak dimana balita yang berusia 6-24 bulan sejumlah 98 anak. Mata pencaharian penduduk di wilayah ini sebagian besar adalah pedagang dengan tingkat pendidikan bervariasi mulai dari lulus SD sampai perguruan tinggi. Dari hasil 
pencatatan bidan desa setempat melalui pencatatan di 3 posyandu yaitu Posyandu Bakti Husada, Flamboyan dan Cempaka, diketahui bahwa balita yang berusia 6-24 bulan di Kelurahan Kampung kajanan ini, beberapa balita ini diantaranya memiliki status gizi kurang dan buruk yaitu sejumlah 14 anak. Dari fenomena ini, hal yang kemudian menjadi penting untuk diperhatikan adalah faktor-faktor yang terkait dengan status gizi balita seperti karakteristik ibu, karakteristik bayi, pengetahuan dan sikap ibu tentang gizi, peran kader posyandu dan bidan desa, media informasi serta riwayat pemberian ASI eksklusif dan susu non ASI serta Makanan Pendamping ASI (MP ASI). Faktor karakteristik ibu seperti suku, umur, tingkat pendidikan, dan agama serta jenis kelamin bayi berpengaruh terhadap keputusan ibu untuk melakukan ASI eksklusif, namun sulit untuk dirubah dalam waktu singkat maupun pada tingkat individu. Beberapa penelitian menunjukkan bahwa pengetahuan gizi ibu berhubungan nyata dengan cara pemberian ASI. Semakin baik tingkat pengetahuan gizi ibu maka pemberian ASI semakin sering (Zai, 2003). Semakin tinggi tingkat pengetahuan ibu tentang ASI maka ibu akan mengetahui cara dan posisi menyusui yang benar serta cara meningkatkan produksi ASI (Adwinanti, 2004). Kurangnya pengetahuan ibu tentang ASI menjadi salah satu penghambat keberlangsungan pemberian ASI (Brown et al, 2003). Sikap ibu berhubungan dengan praktek pemberian ASI. lbu yang menganggap bahwa ASI merupakan makanan terbaik untuk bayi berencana untuk memberikan ASI selama 6 bulan (Foo et al, 2005).

Malnutrisi merupakan masalah gizi yang sering dijumpai di negara- negara berkembang. Peningkatan kemampuan health workers dalam melaksanakan konseling dan komunikasi mampu meningkatkan status gizi balita usia 6- 24 bulan di Brazil dan dapat diterapkan di Negara berkembang lainnya (Zaman, 2008). Upaya promotif dalam menggalakkan program pemberian ASI eksklusif merupakan upaya yang sangat efektif sesuai denagn hasil penelitian yang dilaksanankan di beberapa Negara berkembang dalam kurun waktu 4 sampai 6 minggu dan dievaluasi selama kurun waktu 6 (enam) bulan (Imdad et al, 2009).

Karakteristik balita ditentukan juga oleh berat lahir bayi dimana merupakan indikator penting kesehatan bayi baik dalam dimensi indivdu maupun populasi (WHO, 1995).Inisiasi menyusu dini adalah proses membiarkan bayi menyusu sendiri segera setelah kelahiran. Bayi memiliki kemampuan alami untuk menyusu sendiri selama diberikan kesempatan kontak kulit dengan ibunya (skin to skin contact) setidaknya selama satu jam segera setelah lahir (Roesli, 2008). Bayi yang mengalami skin to skin contact beberapa menit setelah kelahiran akan mencari puting susu dengan kecepatan yang berbeda-beda. Waktu ratarata yang dibutuhkan oleh bayi sekitar 55 menit dan pada banyak kasus dapat mencapai 2 jam (Kroeger and Linda, 2004). Inisiasi menyusu dini merupakan salah satu dari 10 Langkah Keberhasilan Menyusui yang dianjurkan WHO (Menkokesra, 2008). Terdapat lima tahapan dalam inisiasi menyusu dini. Setelah diletakkan diantara payudara ibunya dalam 30 menit pertama, bayi menyesuaikan dengan lingkungan dan sesekali melihat pada ibunya. Tahap kedua, selama sekitar 10 menit kemudian bayi mengeluarkan suara dan melakukan gerakan menghisap dengan memasukkan tangan ke dalam mulut. Tahap ketiga, bayi mengeluarkan air liur. Tahap keempat, bayi menekan-nekan perut ibu untuk bergerak ke arah payudara (breast craw). Terakhir, bayi menjilati kulit ibu, memegang puting susu dengan tangan, menemukan puting dan menghisapnya (Roesli, 2008).

Keadaan status malnutrisi akan membawa dampak yang luas diantaranya mudahnya anak mengalami infeksi serta gangguan tumbuh kembang dan gangguan fungsi organ tubuhnya (Rodrigues and Cervantes, 2011). Status gizi dapat 
diketahui salah satunya dengan metode antropometri yang terbagi menjadi dua jenis, yaitu pengukuran pertumbuhan (ukuran tubuh) dan pengukuran komposisi tubuh (Sarni et al, 2009). Terdapat beberapa cara untuk menilai ukuran tubuh bayi, antara lain lingkar kepala, panjang badan (PB) dan berat badan (BB). Interpretasi dari nilai-nilai tersebut disajikan dalam indeks untuk menilai status gizi bayi. Indeks yang umum digunakan berkaitan dengan umur (U), yaitu indeks $\mathrm{PB} / \mathrm{U}, \mathrm{PB} / \mathrm{BB}, \mathrm{BB} / \mathrm{U}$, dan indeks gabungan ketiganya (Gibson, 2005).

Berdasarkan uraian diatas maka tujuan penelitaian ini adalah untuk mengetahui hubungan pemberian ASI Eksklusif dengan status gizi balita usia 6-24 bulan di Kelurahan Kampung Kajanan Kecamatan Buleleng.

\section{METODE}

Penelitian ini dilaksanakan di wilayah kerja Puskesmas Buleleng I, Kabupaten Buleleng, dimana tempat penelitian ini adalah di Kelurahan Kajanan, Kecamatan Buleleng pada bulan Agustus dan September 2012. Populasi dalam penelitian ini adalah semua ibu yang memiliki balita berusia 6-24 bulan di lingkungan kelurahan Kampung Kajanan Kecamatan Buleleng yang berjumlah 98 orang. Sampel dalam penelitian ini diambil dengan teknik simple random sampling, dengan perhitungan jumlah sampel menggunakan rumus yang dikemukakan oleh Issac and Michael (Arikunto, 2010). Dalam menentukan banyaknya jumlah sampel dari keseluruhan jumlah populasi yang ada mempergunakan rumus sebagai berikut :

$$
S=\frac{\lambda^{2} \cdot N \cdot P \cdot Q}{d^{2}(N-1)+\lambda^{2} \cdot P \cdot Q}
$$

Berdasarkan perhitungan jumlah sampel maka besar sampel dalam penelitian ini adalah 78 orang.

Jenis penelitian yang digunakan adalah penelitian korelasi dengan metode pendekatan cross sectional yaitu penelitian dengan melakukan pengukuran dan pengamatan pada saat bersamaan antara variable dependen dan variable independen. Pengumpulan data dilaksanakan langsung dari sampel penelitian dengan teknik wawancara dengan berbantuan kuesioner sehingga diproleh data primer. Untuk menilai status gizi balita digunakan matriks status gizi yang dikeluarkan oleh Departemen Kesehatan (DEPKES) sehinggga peneliti tidak mengembangkan sendiri. Alat bantu untuk mengambil data adalah meteran dan timbangan berat badan. Pengukuran BB/TB balita dilaksanakan dengan tehnik anthropometri gizi BB/TB balita dalam Kartu Menuju Sehat (KMS). Untuk mengetahui hubungan pelaksanaan pemberian ASI Eksklusif dengan status gizi balita usia 6-24 bulan maka dilakukan analisis data dengan analisis statistik yang digunakan dalam penelitian ini adalah analisis korelasi untuk menguji hipotesis yang ada.

\section{HASIL DAN PEMBAHASAN Hasil Deskripsi Umum Penelitian}

Kelurahan Kampung Kajanan termasuk salah satu diantara 16 kelurahan yang ada di Kecamatan Buleleng, dengan luas wilayah 26,23 $\mathrm{Ha}$. Berdasarkan orbitasinya, posisi Kelurahan Kampung Kajanan berada di wilayah kota Singaraja yang merupakan ibukota Kabupaten Buleleng, yaitu berjarak tidak jauh dari pusat pemerintahan Kecamatan, yaitu 3.5 $\mathrm{km}$. Kelurahan Kampung Kajanan merupakan wilayah pemukiman yang padat penduduk terdiri atas 3 lingkungan yaitu Lingkungan Kajanan Timur, Kajanan Barat dan Kajanan Tengah dan terdiri atas 16 Rukun Tetangga (RT). Jumlah penduduk seluruhnya di Kelurahan Kampung Kajanan adalah 4.660 jiwa atas penduduk laki-laki 2.221 jiwa $(47,6 \%)$ dan penduduk perempuan 2.439 jiwa (52,3\%). Jumlah Kepala Keluarga (KK) di Kelurahan Kampung Kajanan sebanyak 1.364 KK. Keadaan sosial ekonomi atau mata pencaharian penduduk Kelurahan Kampung Kajanan sebagian besar bekerja sebagai 
karyawan di perusahaan swasta dan pedagang.

Karakteristik umum responden menjadi penting agar memperoleh gambaran yang jelas mengenai karakteristik responden pada hasil penelitian. Data yang ditampilkan dalam karakteristik responden adalah data responden yang terpilih sebagai sampel yang merupakan ibu yang memiliki balita usia 6 -24 bulan di wilayah Kelurahan Kampung Kajanan, Kecamatan Buleleng. Usia responden ikategorikan menjadi 3, yaitu $<20$ tahun, $21-30$ tahun dan $>30$ tahun. Distribusi responden berdasarkan usia responden terlihat pada tabel berikut.

Tabel 1. Distribusi Responden Berdasarkan Usia

\begin{tabular}{|c|c|c|}
\hline Usia & Frekuensi & Persentase \\
\hline$</=20$ tahun & 12 & 15,4 \\
\hline $\begin{array}{c}\text { umur } 21-30 \\
\text { tahun }\end{array}$ & 62 & 79,5 \\
\hline umur $>30$ tahun & 4 & 5,1 \\
\hline Total & 78 & 100.0 \\
\hline
\end{tabular}

Dari 78 responden, yang berusia $<20$ tahun sebanyak 12 responden (15,4\%), berusia 21 - 30 tahun sebanyak 62 responden (79,5\%) dan yang berusia $>30$ tahun sebanyak 4 orang $(5,1 \%)$. Keadaan tersebut juga tampak pada gambar berikut;

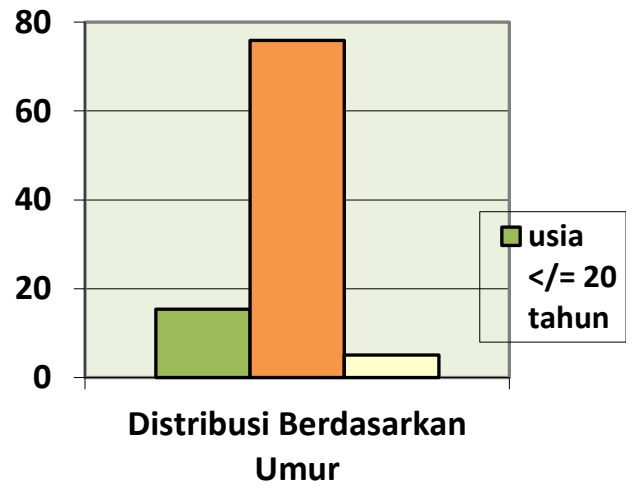

Gambar 1 Persentase Responden Berdasarkan Usia
Tingkat penghasilan keluarga responden dikelompokkan menjadi 3 kategori, yaitu penghasilan $<500$ ribu rupiah, 500 ribu- 1 juta rupiah, dan $>1$ juta rupiah.

Tabel 2. Distribusi Responden Berdasarkan Tingkat Penghasilan

\begin{tabular}{|c|c|c|}
\hline $\begin{array}{l}\text { Tingkat } \\
\text { Penghasilan }\end{array}$ & Frekuensi & Persentase \\
\hline < 500ribu & 15 & 19,2 \\
\hline 500ribu - 1 juta & 55 & 70,5 \\
\hline$>1$ juta & 8 & 10,3 \\
\hline Total & 69 & 100.0 \\
\hline \multicolumn{2}{|c|}{ Dari 78 responden yang memiliki }
\end{tabular}
penghasilan $<500$ ribu rupiah sebanyak 15 responden (19,2\%), responden yang memiliki penghasilan antara 500 ribu - 1 juta rupiah sebanyak 55 responden $(70,5 \%)$ dan yang memiliki penghasilan lebih dari 1juta rupiah sebanyak 8 responden $(10,3 \%)$. Keadaan tersebut juga terlihat pada gambar berikut;

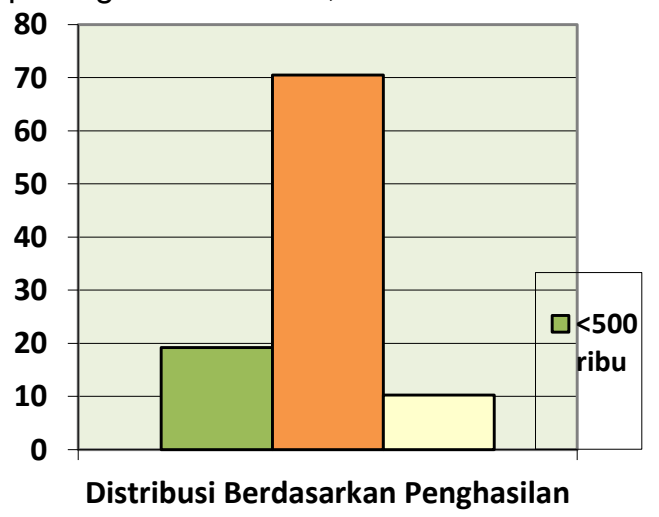

Gambar 2. Persentase Responden Berdasarkan Tingkat Penghasilan

Status pekerjaan responden dikategorikan menjadi 2 yaitu tidak bekerja dan bekerja. 
Tabel 3. Status Pekerjaan Ibu

\begin{tabular}{|l|l|l|}
\hline Pekerjaan & Frekuensi & Persentase \\
\hline Tidak Bekerja & 45 & 57,7 \\
\hline Bekerja & 33 & 42,3 \\
\hline Total & 78 & 100.0 \\
\hline
\end{tabular}

Tabel diatas tersebut menjelaskan bahwa responden dengan status bekerja sebanyak 33 orang (42,3 \%) sedangkan responden dengan status tidak bekerja sebanyak 45 orang $(57,7 \%)$. Hal ini dapat disimpulkan bahwa jumlah ibu yang tidak bekerja jumlahnya lebih banyak yaitu lebih dari separuh jumlah ibu responden di Kelurahan Kampung Kajanan. Keadaan ini juga tampak jelas disajikan pada;

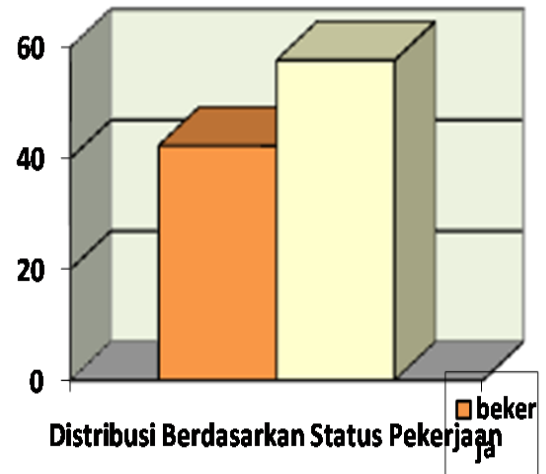

Gambar 3. Status Pekerjaan Responden

\section{Hasil Khusus Penelitian}

Data pemberian ASI Eksklusif dari responden dikelompokkan menjadi kategori, yaitu ibu yang tidak memberikan ASI Eksklusif dan memberikan ASI Eksklusif. Responden yang tidak memberikan ASI Eksklusif sebanyak 19 responden $(24,4 \%)$ dan responden yang memberikan ASI Eksklusif sebanyak 59 responden (75,6\%). Distribusi responden berdasarkan pemberian ASI Eksklusif dapat dilihat pada tabel berikut;
Tabel 4. Distribusi Responden Berdasarkan Pemberian ASI Eksklusif

\begin{tabular}{|l|l|l|}
\hline $\begin{array}{l}\text { Pemberian } \\
\text { Eksklusif }\end{array}$ & Frekuensi & Persentase \\
\hline Tidak & 19 & 24,4 \\
\hline Ya & 59 & 75,6 \\
\hline Total & 78 & 100.0 \\
\hline
\end{tabular}

Distribusi responden berdasarkan
pemberian ASI Eksklusif juga terlihat pada gambar di bawah ini.

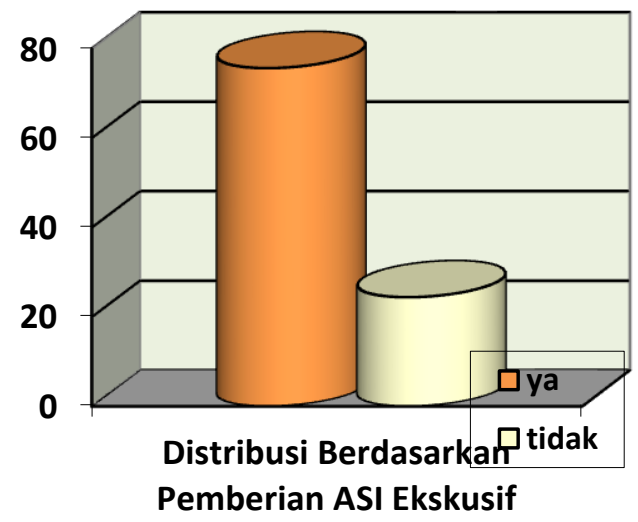

Gambar 4. Persentase Responden Berdasarkan Pemberian ASI Eksklusif

Status Gizi Balita dikelompokkan menjadi 2 kategori, yaitu balita dengan status gizi berada di Bawah Garis Merah (BGM) dan tidak berada di Bawah Garis Merah. Responden yang memiliki status gizi berada di Bawah Garis Merah (BGM) sebanyak 8 responden (10,3\%) dan responden yang memiliki tidak berada di Bawah Garis Merah sebanyak 70 responden $(89,7 \%)$. Distribusi responden berdasarkan status gizi dapat dilihat pada tabel berikut; Tabel 5. Distribusi Responden Berdasarkan Status Gizi Balita

\begin{tabular}{|l|l|l|}
\hline $\begin{array}{l}\text { Status Gizi } \\
\text { Balita }\end{array}$ & Frekuensi & Persentase \\
\hline BGM & 8 & 10,3 \\
\hline Tidak BGM & 70 & 89,7 \\
\hline Total & 78 & 100.0 \\
\hline
\end{tabular}

Jurnal Sains dan Teknologi | 189 
Distribusi responden berdasarkan status gizi balita juga terlihat pada gambar di bawah ini;

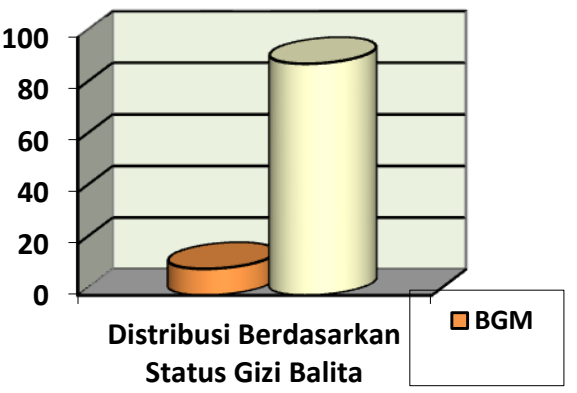

Gambar 5. Distribusi Berdasarkan Status Gizi Balita

Analisis dalam penelitian ini dimaksudkan untuk mengetahui hubungan antara pemberian ASI Eksklusif dengan status gizi balita usia 6-24 bulan di Kelurahan Kampung Kajanan, Kecamatan Buleleng.Hubungan antara pemberian ASI Eksklusif dengan status gizi balita usia 6-24 bulan dapat dilihat pada gambar berikut;

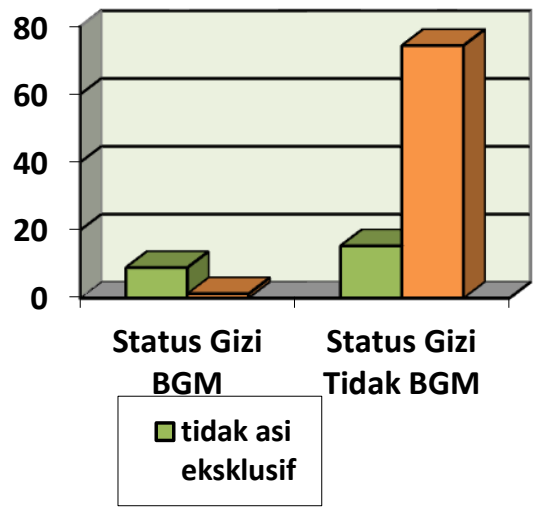

Gambar 6. Hubungan pemberian ASI Eksklusif dengan status gizi balita usia 6-24 bulan

Berdasarkan gambar di atas, menunjukkan adanya kecenderungan bahwa ibu yang memberikan ASI Eksklusif, cenderung memiliki balita dengan status gizi lebih baik dari pada ibu yang tidak memberikan ASI Eksklusif. Hal ini terlihat bahwa ibu yang tidak memberikan ASI Eksklusif, sebanyak $9 \%$ memiliki balita dengan status gizi diatas garis merah dan $1,3 \%$ memiliki balita dengan status gizi di bawah garis merah, sedangkan pada ibu yang memberikan ASI Eksklusif, sebanyak $74,4 \%$ memiliki balita dengan status gizi diatas garis merah dan $15,4 \%$ memiliki balita dengan status gizi di bawah garis merah.

Tabel 6. Hubungan antara pemberian ASI eksklusif dengan status gizi balita usia 6-24 bulan

\begin{tabular}{|l|l|l|l|l|}
\hline \multirow{2}{*}{$\begin{array}{l}\text { Sikap Ibu } \\
\text { tentang }\end{array}$} & \multicolumn{4}{|l|}{ Status Gizi Balita } \\
\cline { 2 - 5 } ASI & \multicolumn{2}{|l|}{ BGM } & \multicolumn{2}{l|}{ Tidak BGM } \\
\cline { 2 - 5 } & $\mathrm{N}$ & $\%$ & $\mathrm{~N}$ & $\%$ \\
\hline Rendah & 7 & 9 & 12 & 15,4 \\
\hline Tinggi & 1 & 1,3 & 58 & 74,4 \\
\hline Total & 8 & 10,3 & 70 & 89,8 \\
\hline
\end{tabular}

Berdasarkan hasil uji korelasi diketahui bahwa nilai signifikansi atau $p=$ 0,000 atau lebih kecil dari 0,05 , hal ini dapat disimpulkan bahwa ada hubungan yang bermakna antara pemberian ASI Eksklusif dengan status gizi balita usia 6-24 bulan.

\section{Pembahasan Hubungan pemberian ASI Eksklusif dengan status gizi balita usia 6- 24 bulan}

ASI merupakan makanan yang higienis, murah, mudah diberikan, dan sudah tersedia bagi bayi. ASI menjadi satu-satunya makanan yang dibutuhkan bayi selama 6 bulan pertama hidupnya agar menjadi bayi yang sehat.Komposisinya yang dinamis dan sesuai dengan kebutuhan bayi menjadikan ASI sebagai asupan gizi yang optimal bagi bayi. ASI dan plasma memiliki konsentrasi ion yang sama sehingga bayi tidak memerlukan cairan atau makanan tambahan (Brown et al,2005). ASI memiliki semua unsur-unsur yang memenuhi kebutuhan bayi akan gizi selama periode sekitar 6 bulan, kecuali jika ibu megalami keadaan gizi 
kurang yang berat atau gangguan kesehatan lain.

Komposisi ASI akan berubah sejalan dengan kebutuhan bayi (Gibney et al,2005).

ASI lebih unggul dibandingkan makanan lain untuk bayi seperti susu formula, karena kandungan protein pada ASI lebih rendah dibandingkan pada susu sapi sehingga tidak memberatkan kerja ginjal, jenis proteinnya pun mudah dicerna. Selain itu, ASI mengandung lemak dalam bentuk asam amino esensial, asam lemak jenuh, trigliserida rantai sedang, dan kolesterol dalam jumlah yang mencukupi kebutuhan bayi (Brown et al,2005). Pertiwi, 2006, dalam penelitiannya "Hubungan Karakteristik ibu dengan pemberian ASI Eksklusif dengan penyakit infeksi dan status gizi pada balita yang dilaksanakan di Semarang", diperoleh adanya hubungan antara usia, pekerjaan , pengalaman menyusui sebelumnya dan tingkat pendidikan ibu dengan status gizi balita hubungan dengan sgnifikanis statistik $\mathrm{p}=0,017$ ditemukan pada pengujian hipotesis adanya hubungan antara lama pemberian ASI Eksklusif dengan status gizi balita.

\section{SIMPULAN DAN SARAN}

\begin{tabular}{llr}
\multicolumn{2}{c}{ Berdasarkan hasil uraian } \\
pembahasan penelitian maka dapat \\
disimpulkan ada hubungan antara
\end{tabular} pemberian ASI Eksklusif dengan status gizi balita usia 6-24 bulan, dimana ibu yang memberikan ASI Eksklusif akan semakin baik status gizi balitanya dari pada ibu yang tidak memberikan ASI Eksklusif kepada balita yang berusia $6-24$ bulan.

$$
\text { Adapun saran yang diperoleh }
$$
berdasarkan simpulan daiatas maka kepada; Tenaga Kesehatan, diharapkan agar lebih meningkatkan promosi kesehatan gizi balita, melalui pemberian pendidikan kesehatan dalam bentuk penyuluhan mengenai pentingnya ASI Eksklusif bagi balita. Bagi ibu, diharapkan agar lebih memperhatikan asupan gizi bagi balitanya serta memberikan ASI kepada bayinya secara Eksklusif dan dilanjutkan hingga usia 2 (dua) tahun. Bagi Peneliti Selanjutnya untuk mendapatkan hasil yang objektif dan menyeluruh hendaknya mengadakan penelitian yang lebih cermat terhadap faktorfaktor yang mempengaruhi status gizi balita terlepas dari faktor pemberian ASI Eksklusif.

\section{DAFTAR PUSTAKA}

Arikunto S. 2010. Prosedur Penelitian Suatu Pendekatan Praktik. Jakarta: Rineka Cipta.

Badan Pusat Statistik. 2003. Indonesia Demographic and Health Survey 2002-2003. Calverton, Maryland, USA: BPS and ORC Macro.

Brown JE, Dugan $\mathrm{C}$ and Kleindan $\mathrm{R}$. 2005.Nutrition Through the Life Cycle. Balmont, USA: Thomson Wadsworth.

Foo LL, Queck SJS, MT Lim, and Deurenberg-Yap M. 2005. Breastfeeding prevalence and practices among Singaporean chinese, malay, and indian mothers. Health Promotion International 20(3).

Gibney MJ, Barrie MM, John MK, and Leonore A. 2005. Public Health Nutrition. Oxford: Blackwell Publishing Ltd.

Kementrian Negara Koordinator Kesejahteraan Rakyat. 2008. Ibu Negara Serukan Inisiasi Menyusu Dini.

Didapatkan Dari halaman http://www.menkokesra.go.id/content. Diakses pada tanggal 13 Februari 2012

Kroeger M and Linda JS. 2004. Impact of Birthing Practices on Breastfeeding: Protecting the Mother and Baby Continum. Massachusetts: Jones and Bartlet Publishers.

Jurnal Sains dan Teknologi | 191 
Pertiwi AD. 2006. Hubungan Karakteristik ibu dengan pemberian ASI Eksklusif dengan penyakit infeksi dan status gizi pada balita. Semarang, Universitas (Tesis) Didapatkandarihalamanwww.eprints. undip.ac.id/26158/1/52_Aries_Dian_ P_G2C204105.doc_A.pdfDiakses pada tanggal 10 Oktober 2006

Rodríguez L and Cervantes E. 2011. Malnutrition and gastrointestinal and respiratory infections in children: a public health problem. Available at Int $\mathrm{J}$ Environ Res Public Health. 2011 Apr;8(4):1174-205. Epub 2011 Apr 18.Diakses pada tanggal 13 Februari 2012

Roesli U. 2008. Inisiasi Menyusu Dini Plus ASI Eksklusif. Jakarta: Pustaka Bunda.

Sarni RO, Carvalho MF, Monte $\mathrm{CM}$ and Albuquerque ZP. 2009. Anthropometric evaluation, risk factors for malnutrition, and nutritional therapy for children in teaching hospitals in Brazil. Available at $\mathrm{J}$ Pediatr (Rio J). 2009 May-Jun;85(3):223-8. Diakses pada tanggal 7 Februari 2012

Sarni RO, Carvalho MF, Monte $\mathrm{CM}$ and Albuquerque ZP. 2009. Anthropometric evaluation, risk factors for malnutrition, and nutritional therapy for children in teaching hospitals in Brazil. Available at $\mathrm{J}$ Pediatr (Rio J). 2009 May-Jun;85(3):223-8. Diakses pada tanggal 7 Februari 2012

WHO. 1995. WHO Expert Committee on Physical Status: the Use and Iterpretation of Antrophometry. Geneva: WHO. Didapatkan dari halaman.

staff.ui.ac.id/.../PENILAIANSTATUSG IZIBALITAANTROPOMETRI.

Zai HE. 2003. Pola pemberian ASI dan MPASI serta status gizi anak baduta di Desa Maliwa'a dan Desa Bobozioli Loloana'a Kecamatan Idanogawo Kabupaten Nias Propinsi Sumatera Utara. Bogor: Fakultas Pertanian, IPB

(Tesis).Didapatkandarihalamanwww.r epository.ipb.ac.id/...\%201I1\%20Pikir \%20l09araan \%20l09araDiakses pada tanggal 2 Oktober 2011

Zaman S, Ashraf RN and Martines J. 2008. Training in complementary feeding counselling of healthcare workers and its influence on maternal behaviours and child growth: a cluster-randomized controlled trial in Lahore, Pakistan Available at $J$ Health Popul Nutr. 2008 Jun;26(2):210-22.Diakses pada tanggal 13 Februari 2012. 